New Test. Stud. 8, pp. 1-11.

\title{
E. SCHWEIZER
}

\section{THE CHURGH AS THE MISSIONARY BODY OF GHRIST}

The life or death of a church depends on how much its members are willing to proclaim the gospel to the world. If its ministers are satisfied merely with performing their functions and counselling religious people, if its members confess their faith just as far as it is socially acceptable, the church will grow more and more into a sterile institution that is far from the living church of the New Testament. The purpose of this study is therefore to ask what connexion may exist between the church and its mission to the world in both the generally accepted and in the disputed letters of Paul. ${ }^{1}$

For four centuries the Letter to the Romans has been interpreted in the shadow of the mighty and revolutionary new attempt of Martin Luther to understand its message. Consciously or unconsciously this letter is read with Luther's question in mind, and thus an answer is expected to the individual problems of souls tortured by feelings of guilt. According to this view Romans depicts the way of individual salvation, chapters $\mathrm{i}-\mathrm{iii}$ describing the sin, iii-viii the reconciliation, and xii-xv the obedience of the redeemed sinner. This, of course, is the understanding of our catechisms, of Melanchthon's Loci as well as of the Heidelberger. If, however, we face the situation as given by the text itself, this answer seems to be insufficient.

As early as the preface we detect Paul's main interest. He presses an unusual number of statements into the traditional pattern. In the very first verse Paul focuses upon God's eschatological deed which set him apart for the proclamation of the gospel. Paul's mandate is described in $v .5$ as the event of God's grace which, through the mission to the gentiles, brings about the obedience of all nations. To fulfil this mission is Paul's intention when writing this letter. In between $v v$. I and 5 Paul inserts a creed quoted from a probably well-known confession of faith. The introductory $v .2$, which is Paul's own formulation, shows again his interest in God's plan of salvation

1 The form of this lecture delivered at Durham, Edinburgh, St Andrews and Cambridge in March $196 \mathrm{I}$, remains unchanged. I therefore did not supply it with additional footnotes. For parts II and IIt they may be found in my article soma in G. Kittel and G. Friedrich, Theologisches Wörterbuch zum Neuen Testament, for part III also in my article 'Die Kirche als Leib Christi in den paulinischen Antilegomena', in Theologische Literaturzeitung (1961), pp. 24I ff. For part I I learned most from A. Schlatter, Gottes Gerechtigkeit (1 935 ) and from occasional discussion with E. Käsemann whose commentary on the letter to the Romans is eagerly awaited. I did not see, till this essay was completed, the article of G. Eichholz, 'Der ökumenische und missionarische Horizont der Kirche, eine exegetische Studie zu Röm. I, 8-15', in Evangelische Theologie (1961), pp. 15-27. 
according to which the gospel has been foretold in Israel. The creed itself fits into this pattern. Different in both terminology and content from Paul's own writings it speaks of Christ being born as son of David and installed as son of God by his resurrection. It is a concept of heilsgeschichte in which Christ is seen exclusively as the fulfiller of Israel's history and as the eschatological ruler. Thus the whole preface proves Paul's concern with God's way of salvation, as it is, in the times of Israel, described in Scripture, and, in the time of Paul, manifested in his mission to the gentiles under the kingship of the exalted Lord.

Even more important is the introductory part of the letter, i. 8-I5, leading up to the famous vv. I6f. which form something like a title of the whole letter. The first verse praises the addressees because their faith is proclaimed in all the world. This may well seem to be an exaggeration. But it shows how the cosmic dimension is continually in the foreground when the proclamation of the gospel is in question. Now, in the eschatological time, the whole cosmos is the field of God's revelation and of man's obedience. Paul then expresses his deep personal longing to meet his readers, but even here he presses the point that they rank among the gentiles to whom he is sent by God himself. This point is further developed in vv. I4f. where Paul mentions the divine compulsion determining his course among the nations. $\mathrm{He}$ is under divine obligation to preach the gospel everywhere among the gentiles. Exactly this is the place for inserting the famous heading of the whole letter. 'For I am not ashamed of the gospel: it is the power of God for salvation to every one who has faith, to the Jew first and also to the Greek. For in it the righteousness of God is revealed...' This heading is totally mistaken when understood as merely describing the salvation of an individual. It is Paul's reinterpretation of Ps. xcvii (xcviii). $2 \mathrm{f}$. depicting the eschatological coming of God: 'The Lord has made known his salvation, he has revealed his righteousness in the sight of the gentiles.... All the ends of the earth have seen the salvation of our God.'

From this the structure of the main body of this letter becomes clear. i. I8-iii. 20 deal with the eschatological outburst of God's wrath. It takes place in the proclamation of the gospel, since $v$. I 8 ("For the wrath of God is revealed...') is an absolute parallel to $v$. I7 ('For in it, the gospel, the righteousness of God is revealed...'). Both verses are connected with Paul's statement that he is bound to preach the gospel to the gentiles (vv. I4f.) through the threefold 'for' introducing the proof for this statement. Thus God reveals his righteousness by no longer holding back his wrath. This happens in the proclamation of the gospel all over the world as a proleptic last judgement, in which he tears the mask from all faces, annihilating all boasting of wisdom among the gentiles or of legal perfection among the Jews. Therefore in this mission of Paul the lawsuit of mankind versus God, of which the Old Testament speaks so frequently, is being decided. The issue is 
indubitable. God will 'be justified... and prevail when being judged' (iii. 4), which formula again is a reinterpreted Old Testament text. This means that 'every mouth will be stopped and the whole world be held accountable to God' (iii. 19). This acknowledgement by the succumbing party is an important part of the lawsuit described in the Old Testament.

And yet the promises of God are not abolished. It is the unexpected wonder of God's grace, dealt with in chapters iii. 2 I to viii. 39, that God proves himself not only as righteous but also as bestowing righteousness upon men. Again the crucial point is the mission to the gentiles. That they are called to faith proves that every mouth has been stopped and that all glory belongs exclusively to God. This, however, is exactly what God had foreseen in his plan of salvation. Abraham is 'the father of many nations' (iv. 17 f.), of the gentiles as well as of the Jews (iv. IIf.). And Christ embraces the whole history of the world, since he is the eschatological Adam inaugurating a new mankind (v. I 2-2I). The problem of the law setting apart an elected people is in the background of Paul's discourse throughout (cf. iv. I3-16; v. 2of.). It is dealt with explicitly in chapters vi and vii. Chapter viii shows again that Paul is not mainly interested in the individual's salvation, but in the redemption of the cosmos including all creatures, in which God himself gains his ends. Only from this angle can chapters $i x-x i$ be understood, neither as an irrelevant left-over of a long-since overcome standpoint, nor as an unrepeatable treatise of a doctrine of predestination, but as an expression of Paul's main concern, namely that the mission to the gentiles is the eschatological token of the indubitable victory of God. This universal mission does not mean God's shifting to a new plan of salvation, but its very fulfilment, because all nations will be brought into God's kingdom together with the whole body of Israelites. This mission is therefore an important part of God's plan bringing about its very end. Using Luther's problem as touchstone the interpreter would reach a dead end at viii. 39 . But chapters xii-xv are the logical and equally important conclusion of the letter, if seen in connexion with the problems mentioned above. They depict the universal obedience of God's people who give all the glory to him. For this God's lawsuit comes to its end He is justified by the fact that all nations accept his verdict, succumb to his vindication and praise his sole righteousness. And only by doing so mankind also is justified in God's judgement. Paul's mission to the gentiles remains his central concern at the end of the letter. Nowhere else does Paul speak with so much pathos. The apostle is the cosmic priest presenting all nations of the earth as an acceptable thank-offering to God. From Jerusalem to Illyricum he has brought the gospel to its fullness. At present, he is fulfilling his course by going via Rome to Spain-to land's end where the ocean separates earth from the abyss. Again, reinterpreting an Isaianic passage, namely, the prophetic vision of the mountain Jerusalem to which all nations are brought as an offering to God (lxvi. 20), Paul shows 
that the obedience of the gentiles is the longed-for fulfilment of the heilsgeschichte (xv. 16-29). Thus Paul sees the mission to the nations as the decisive event before the end inaugurated by Christ's exaltation, going on as Christ's own work, concluded by Christ's parousia. The whole church takes part in this mission by its intercession which is asked for in the very last verses of the letter $\left(\mathrm{xv} .3^{0}-3\right)$. However, this mission to the world is not yet combined with other concepts, with either the body of Christ idea or the pattern of Christ as the mystery hidden for ages and revealed in the gospel. Let us turn to these points.

It goes without saying that, on two or three pages, we cannot treat thoroughly the concept of the body of Christ. May I be allowed to point to just one problem? The history of the word 'body' is interesting enough. The Hebrew language knows no term for 'body'. As J. A. T. Robinson rightly states, the Hebrew mind distinguishes neither form and matter as opposing each other, nor the one and the many, nor soul and body. Man as a whole is ' $f l e s h$ ', when considered as earthly creature, subject to illness, weakness, death. As an individual he shares his 'fleshliness' with all mankind, so that the same term may designate man or mankind. When Hebrew writings had to be translated into Greek the translator was forced to choose between 'flesh' and 'body'. This process may be watched in the Septuagint. By and large, 'body' is preferred when man experiences something that affects his whole person, for example, illness and healing, death and resurrection, or sexual love. However, 'body' always means man's physical corporeity which, for the Hebrew mind, includes the psychic experiences. As it is to be expected, it describes the individual man, on the whole not as acting, but as suffering, and may even be used for singling out individuals.

When Paul takes up this term, he is, first of all, a Greek-speaking Hebrew. For him, 'body' does not mean a separate part of man, even less than 'flesh'. It means man as a whole when his physical-psychical corporeity is stressed. However, the statistical evidence leads us some steps further on. Excluding the special usage of 'body' meaning 'corpse' or 'slave', we find that, even by counting the synoptic passages two or three times, out of 124 occurrences ninety-one are to be found in the Pauline letters (excluding the Pastorals). Focusing on the generally accepted letters, we meet the term sixty-nine times in the letters to the Corinthians and the Romans-the latter written in Corinth-and only four times elsewhere. This is illuminating. The term 'body' had been shaped in the discussion of the apostle with his opponents in Corinth. There Paul met a theological concept of man's divine 'spirit' being the only essential part of him. According to that, the physical body was to be taken off in death whereas the long-since deified spirit simply lived on, so that no further resurrection was needed (I Cor. xv. I2). The physical body with its boundaries and limitations was also left behind when speaking 
in tongues which was considered the supreme gift of God (I Cor. xii. I4). For the physical body 'all things were lawful' (I Cor. vi. I2), since nothing mattered. Knowledge about this inner divine essence was the only essential thing, one's fellowmen were unimportant, even nuisances, if they did not possess the same wisdom (I Cor. viii. I ff.). The Lord's supper was a medicine for immortality; therefore it did not matter at all how one conducted the meal which preceded it (I Cor. xi. I 7 ff.). In opposition to such a concept, Paul presses the point that it is exactly in the body, that is, man in his earthly life, in the wholeness of his existence, that faith is to be lived. Paul even goes as far as to assert that there is no other sin as dreadful as sexual immorality, since this, more than any other sin, affects the body that belongs to the ILord as the Lord belongs to the body. To be sure, 'body' is carefully distinguished from 'belly', that is, from the mere physical functions of the body. Thus Paul takes for granted that sexuality is never a merely physical function, but an act that affects the whole personality. However, just because it affects the physical body as well as its psychical side, the sexual life is a first-class opportunity for the expression of faith and not negligible at all. It is, for Paul, particularly the body in which one proves one's faith true. Therefore Paul prefers this term in those passages in which he declares that the indicative proclaiming the salvation in Christ includes the imperative telling the believer how to live as the saved one. Thus the introductory verse of the so-called ethical part of the letter to the Romans, xii. I, runs: 'I appeal to you therefore by the mercies of God to present your bodies as a living sacrifice...' Similarly, vi. I 2 marks the boundary-line between Paul's proclamation of the reconciliation and his admonition to a life within the state of the reconciled man: 'Let not sin therefore reign in your mortal bodies.' With reference to Christ himself, 'body' means his person given for the sake of the world. It is neither his personality reaching perfection in itself nor the mere conglomerate of bones and muscles. His 'body' is, as in Rom. vii. 4, Christ himself in his 'for-our-sake-ness'. Thus 'body' never means, as it would in a purely Greek understanding, the individual as a micro-cosmos, limited in itself, nor, as Bultmann (Theology of the $\mathcal{N} . T$. $\S \mathrm{I} 7,2$ ) puts it, man in distance from himself, as object of his own action or experience.

This usage of the term 'body' would open the way for an understanding of the body-of-Christ concept in which the church would be considered as the instrument by which Christ did his continuing service to the world. That this does not yet appear in the undisputed letters is due to the fact that the image of the body of Christ is rooted in other conceptions which we cannot discuss here, namely $(a)$ in the Jewish idea of corporate personality, particularly in the idea of the patriarch determining the destiny of his tribe; $(b)$ in the Stoic usage of 'body' designating the unity and wholeness of an organism, for example, a people or an ekklesia (= public meeting), and (c) in the theological concept of the church living 'in Chris': , that is, in the 
realm of blessing and challenge still emanating from his body crucified and risen for the sake of the church. None the less, in Rom. xii, Paul shows that the members of the body of Christ are rendering their services to the world as well as to one another. Thus all the ideas are ready for a new understanding in which the term 'body' might carry with itself all the connected meanings when used outside of the body-of-Christ idea.

While this is true for the terminology, it is also true for the content itself of this idea. The proclamation of the gospel to the gentiles, as we have seen, is for Paul an eschatological event of first importance. Moreover, Paul speaks in the terms of Jewish apocalypticism of the mystery hidden for ages, not known to the powers, but now unveiled for the elect ones. This mystery is Christ crucified for the sake of the world (I Cor. ii. 6-Io). Again these two ideas are connected neither with each other nor with the body-of-Christ idea. But there are theological concepts pregnant for further development.

III.

This further development takes place in the letter to the Colossians. It is not important for our purpose to decide whether this is a genuine letter of Paul or, as I think, one written by an intimate disciple. Nor is it so exceedingly relevant whether one accepts or rejects the following attempt to reconstruct the original hymn in Col. i. 15-20. My main purpose is to show that, in the background of this letter, there is a development of Pauline thought into a Hellenistic conception of a cosmic Christ, fascinating and dangerous at the same time, and that this conception is corrected by the author of this letter into a genuine Pauline understanding. Even if one thinks that a reconstruction of the very words of the Colossian hymn is no longer possible, one would probably not deny that there are cosmic ideas in the background.

Most commentators, however, agree that in Col. i. 15-20, there is a piece of Colossian theology, either a hymn or a thanksgiving formula or another part of a liturgy, quoted and enlarged, perhaps even changed, by comments of the reinterpreting author to the Colossians. As commentators are far from reaching any agreement about the original extent of this hymn, I may be allowed to try anew. Let us start with observing the fact that there are three couplets of exactly parallel lines:

$H e$ is the image of the invisible God, the firstborn of all creation, for in him all things were created, in heaven and on earth, through him and for him all things have been created.

$\mathrm{He}$ is the beginning, the first-born of the dead, for in him all the fullness was pleased to dwell, through him to reconcile to him all things.

The parallelism of these two stanzas is even more striking, if one recognizes that 'image' and 'beginning' are two interchangeable predications of the heavenly Wisdom (Philo, Leg. All. I, 43; Conf. Ling. 146). Between these 
two stanzas there is a three-lined stanza which connects the first and the second one by underlining that there is one who is both creator and saviour of all things:

And it is he who is before all things, and in him all things hold together, and it is he who is the head of the body.

The theology of the group that created this hymn is obvious. One could quote the parallels to the first stanza word by word in the Wisdom literature. It depicts Christ as the mediator of creation, in whom all things, in heaven and on earth, are explicitly included. However, there is a new tone in it, although not totally unparalleled in Stoic hymns, namely the eschatological view that all things are created for him. The intermediate stanza states that it is the one and the same Christ who holds together the cosmos and thus preserves the world from dissolution. He, Christ, is therefore the head of the cosmos. This is the Christian reinterpretation of the well-attested Hellenistic concept of the cosmic body ruled by God, either Zeus or Ether, Logos or Heaven, as its head. Finally, the second stanza contains the new message. In Christ heaven and earth are reconciled again. This is the answer of that Christian group in Colossae to the main problem of Hellenistic man: the feeling of being an alien on this earth, irreparably separated from heaven, that is, from a life with the gods, from any real happiness and from any existence rich in meaning.

All this is a theological development almost inevitable, as soon as Pauline thoughts were interpreted by Hellenists. For centuries they thought of the world as of a living and divine body, and of God as of its ruler, governing it as its head or permeating it as its soul, or surrounding it like the air in which it lives, or like the womb of a mother. Man in this Hellenistic area was not so much worried with his personal problems, his sin and his righteousness, as with the problem of this world, the meaninglessness of life, the threat of an unavoidable fate, the tyranny of the heavenly rulers, that is, the stars that determine every move of earthly life. In this world a Christian group, having learnt much from Paul, sang its hymns praising Christ as the one Creator and Saviour of the cosmos to whom all powers are subject.

The author to the Colossians takes up such an interpretation. Indeed, Christ is not only Saviour of the individual redeeming from sin and leading him to a pious life. He is Lord of the whole world. He is not only the answer to specifically religious problems, for consciences tortured by sinfulness and longing for forgiveness. He is also the answer to modern Hellenistic problems in a world that had lost God and therefore its aim, its meaning, that is bound to meet its fate, that was full of fear and yet not able to evade it. However, the writer of Colossians cannot repeat this hymn without comment. Unfortunately, not being in the happy position of a modern commentator who may give his interpretation in a lot of footnotes or in small print between the 
lines of the original text, he has to insert his commentary into the hymn and to add it at the end. It is exactly this that he did. Let us therefore turn to the clauses in Col. i. I 5-20 omitted hitherto.

His first comment is to be found in 0.16 . "All things in heaven and on earth ' are interpreted as 'thrones or dominions or principalities or authorities.' This is merely a clarification of the statement in the hymn, and relating it to the special problem of this letter, the subordination of all heavenly powers to Christ. The last two terms appear again in the discussion of this problem in ii. Io and I5. The second comment is more important. Whereas the hymn only refers to the cosmos when proclaiming Christ as the head of the body, the author to the Colossians adds his reinterpretation: 'namely of the church'. As for Paul in all his letters, so for the author to the Colossians the body of Christ means the church. The same is to be found outside of the hymn in i. 24 where the writer explains: 'his body, that is, the church'. Also, in ii. I9, the growing body must be the church. This correction is needed. For the unchanged statement of the hymn would inevitably lead to a conception of redemption as a mere physical or metaphysical event. Man would then be redeemed when he perceives that nature has been overcome by a miraculous divine power. Redemption would be thought of in terms of nature, not in terms of 'historicality', or, if we dislike this contrasting word, 'of grace and challenge', that is, of a personal gift of love and a personal claim for obedience. The third comment is the short clause in $v$. 18: 'that in everything he may be preeminent'. This again is a reinterpretation in the Pauline sense. The assertion of the hymn that all powers are reconciled to God or Christ, is unique in the New Testament. Only in a hymn of a similar kind, in Phil. ii. 9-II, is there anything comparable, although, in the latter, it is much more cautiously stated. In opposition to such a universal reconciliation, the author to the Colossians stresses the absolute superiority of Christ, as he does in a more elaborate way elsewhere in his letter. In ii. Io, for instance, he interprets 'head' as signifying Christ's superiority 'over all rule and authority'. This is the sole meaning of this term, when used metaphorically, in both the Septuagint and Paul's main letters (cf. I. Cor. xi. 3). He even illustrates this more clearly in ii. 14 : ' $\mathrm{He}$ disarmed the principalities and powers and made a public example of them, triumphing over them.' This is certainly not a reconciliation but an overcoming, a 'pacifying' in the sense in which Roman emperors used it. Finally, at the end of the hymn, he adds, a bit awkwardly, the clause: 'making peace by the blood of his cross.' Into a theology focusing exclusively on resurrection and exaltation, probably understood as the physical event that connected earth and heaven anew, he introduces the Pauline stress upon the cross as the redeeming act of Christ. Exactly the same is true for ii. 14, the passage referred to just now. There, too, the image of a triumphant entry of the victor followed by his prisoners points to the ascension of the Lord, but the author relates it to his death by the 
clause 'nailing the bond to the cross'. We may, therefore, draw the conclusion: all clauses exceeding the rhythmical order and the parallelism of the supposed original hymn agree with the theological conceptions of the author of the letter, and, with the exception of the first one, disagree with the conceptions of the hymn. The first clause also relates the statement of the hymn to the actual situation in Colossae, as the author of the letter sees it.

Even more illuminating is the broader commentary that follows the hymn immediately. Again the fact is stressed that it is mankind, not nature, that is reconciled, that this happened through Christ's death on the cross, and that it led to faith and hope, not to a renewed nature. The clause that interests us most, however, is the last one in 0.23 . In it the author takes up the problem of Hellenistic man, as it emerged in Colossae, and the concern of the group which tried to give an answer to it in the words of the hymn. $\mathrm{He}$ agrees with these Christians in Colossae in stating that Christ indeed is a saviour, not only for individuals but for the world, and that he indeed is permeating the cosmos. However, he disagrees with them in saying that Christ does so, not by being a mysterious spiritual power like the Stoic world-soul or like some divine atmosphere wrapping in the whole world; Christ permeates the world, according to Col. i. 23, in 'the gospel which you heard, which has been preached to every creature under heaven, and of which I, Paul, became a minister'.

The preaching of the gospel to the world, Christ among the gentiles, is, according to the following verses, the mystery hidden for ages, now revealed. It is the eschatological fulfilment of God's plan of salvation (i. $26 \mathrm{f}$.). Terms found in Wisdom literature and Jewish apocalypticism are used in the description of this miracle of the gospel proclaimed to the whole world (cf. i. $25-8$; ii. 2 f.). However, the author reminds us, we should not forget that this mission to the world can never be carried through by a church feeling rich, possessing all the treasures of knowledge and distributing them graciously to poor gentiles. Immediately after his comment in $v .23$, and before speaking of the mystery once hidden, now unveiled, he shows that this preaching goes on in the suffering which Paul takes upon himself for the sake of Christ's body, since only in a church ready to suffer and be humiliated is the preached gospel proved trustworthy. How else could the gentiles believe in the message that God's grace is sufficient for the world, and that God's power is made perfect in weakness?

Other passages show much the same development of an originally physical understanding of Christ's permeation of the cosmos into a reinterpretation relating it to the church's mission to the world. Col. i. 5 f. proves that the topic of the growing body of Christ is connected with the idea of the gospel bearing fruit and growing universally in the whole world. Eph. ii. I I-22 and iii. $1-13$ develop these ideas further. There is also a pattern probably originally describing the cosmic dimension of Christ's saving act in physical terms 
reinterpreted in the thought that the church grows out of Israel into a universal body including all nations. This may explain ii. I 7 which turns up quite unexpectedly. It speaks of Christ's proceeding all over the world in the preaching of the gospel to those who are far and those who are near, an idea which may have been originally connected with Christ's ascension, as H. Schlier conjectures in his commentary. Chapter iii again speaks of the salvation of the gentiles in the terminology of the Wisdom writings and apocalypses. It even widens the function of the church's preaching to the world into its proclaiming the revealed mystery to the heavenly powers and principalities (iii. 10). In some way one may say that this reinterpretation is already prepared for by Paul himself, when, in Rom.x. I8, he reinterpreted Psalm xix. 5 which describes all nature praising God and applies it to his mission to the farthest corners of the earth. Possibly the clearest parallel to the theological development shown in Col. i. I $5 \mathrm{ff}$. is the hymn preserved in I Tim. iii. I6. Here again a physically understood permeation of the cosmos in Christ's ascension is reinterpreted by the reference to his permeation of the world in the preaching of the gospel: 'Manifested in the flesh (namely when incarnated), vindicated in the spirit (according to all parallels: in his resurrection) seen by angels (probably prostrated before the victor), preached among the nations, believed on in the world, taken up in glory.' However, there is no space left to deal with these developments. (Cf. also Diognetus, vi. I-8; Ignatius, Smyrn. i. 2; Irenaeus, Haer. Iv, xxxiii. 7; v, xvii. 4; Hippolytus, Refutatio v, viii. 22.)

\section{IV}

We may summarize: From its roots in the Jewish patriarchal idea and in the Stoic use of the term, the body-of-Christ concept stresses first of all the unity between Christ and his church and between the members themselves. The normal usage of the term 'body', however, points with Paul to man's responsibility towards God and his fellowmen. Furthermore, for Paul, his mission to the gentiles is an eschatological event of first importance. Hellenistic groups, however, were primarily concerned with Christ's lordship over the cosmos and its ruling principalities, over the inevitable fate and over all those powers that had escaped man's control and frightened him. Accordingly a Christian group reinterpreted Paul's term of the body of Christ in a way familiar to every Hellenist: Christ is the world-soul permeating and ruling the whole cosmos; as such he-and not Zeus or Ether or any God of a mystery religion-became, in his ascension, the head of the universe. The author to the Colossians (Paul himself in his later years, or one of his disciples) takes up this problem and this answer and reinterprets it anew. Christ is indeed the Lord over the world. This, however, is not merely a physical phenomenon that one simply takes for granted, since the decisive fact had happened long since and outside of oneself. It claims our faith and obedience. This is so, because it is just in his body, the church, that Christ is 
permeating the world. Thus it is in the preaching to the world and in the suffering for the world that this lordship of Christ over the world is established. Claiming our bodily obedience-even to the exposure of Paul's body to scourging in various prison-courts-Christ, through his body, is searching and finding the world, permeating it, blessing it, rendering it obedient to himself. Thus, as so often in the history of the church, heresy became the pacemaker of a strongly needed orthodox reinterpretation, and by this orthodoxy was saved from becoming an extreme heresy by its unchanged repetition of old creeds in a changed situation. 